\title{
De marcar la cancha a una canchereada na metaforização da política pelo futebol: análise de unidades fraseológicas especializadas em corpus jornalístico argentino
}

\section{From "marcar la cancha" to "una canchereada" in the metaphorization of politics by football: analysis of specialized phraseological units in Argentinean journalistic corpus}

\author{
Ariel Novodvorski \\ Universidade Federal de Uberlândia (UFU), Uberlândia, Minas Gerais / Brasil \\ arivorski@ufu.br \\ http://orcid.org/0000-0003-1370-8334
}

Cleci Regina Bevilacqua

Universidade Federal do Rio Grande do Sul (UFRGS), Porto Alegre, Rio Grande do Sul / Brasil

cleci.bevilacqua@ufrgs.br

http://orcid.org/0000-0002-1002-9080

Resumo: Este artigo apresenta uma análise de termos e unidades fraseológicas especializadas, do âmbito do futebol, em processos de metaforização com o domínio alvo da política. A pesquisa utiliza um corpus jornalístico monolíngue em espanhol rio-platense, da coluna Humor Político do jornal argentino Clarín. A utilização de programas computacionais para análises lexicais característicos da pesquisa com a Linguística de Corpus viabilizou a identificação e extração de termos e fraseologias especializadas presentes no corpus. A análise das unidades em contexto apontou para a construção metafórica do campo mais abstrato da política por meio de figuras mais concretas do meio futebolístico. A consulta a corpora disponíveis on-line corroborou as premissas e os achados no corpus de estudo.

Palavras-chave: terminologia; unidades fraseológicas especializadas; metáfora; linguística de corpus; corpus jornalístico. 


\begin{abstract}
The following paper provides an analysis of soccer terms and specialized phraseological units in metaphorization processes with the target area of politics. The research uses a monolingual journalistic corpus in Spanish rio-platense, from the politics section Humor Politico of the Argentinean newspaper Clarín. The use of computer programs for lexical analysis typical of Corpus Linguistics research has made it possible to identify and extract terms and specialized phrases found in the corpus. The analysis of units in context pointed to the metaphorical construction of the most abstract field of politics by means of more concrete figures of the soccer environment. The corpora consultation available online corroborated the premises and findings in the corpus of study.
\end{abstract}

Keywords: terminology; specialized phraseological units; metaphor; corpus linguistics; journalistic corpus.

Submetido em 31 de agosto de 2020

Aceito em 19 de outubro de 2020

\title{
1 Introdução
}

Este artigo é um recorte da pesquisa de Pós-doutorado do primeiro autor deste texto, junto ao PPG-Letras da UFRGS, com conclusão prevista para dezembro de 2020. Essa pesquisa nasce da exploração de diferentes corpora, monolíngues, comparáveis e paralelos, no par linguístico espanhol/português, compilados a partir da seção de opinião de jornais argentinos e brasileiros, com a trama política desses países como tema principal e a observação das características lexicais, como objeto de estudo. A motivação para a escolha da temática e consequente compilação dos corpora partiu de nosso interesse, por um lado, pelo acompanhamento da situação e trama política na região, enquanto leitores de diferentes jornais de ampla circulação e de livre acesso on-line e, por outro lado, pela análise das combinatórias lexicais identificadas a partir de unidades terminológicas, em uma perspectiva contrastiva e comparável. ${ }^{1}$ Apresentamos parte desse material e dos resultados em

\footnotetext{
${ }^{1}$ Do ponto de vista da Metáfora Conceptual, das características do corpus e da utilização de ferramentas da Linguística de Corpus, os trabalhos de Berber Sardinha (2007a, 2008, 2010) e de Sperandio (2009, 2010) são pontos de contraste relevantes com esta pesquisa, como será observado na seção teórica, por abordarem o estudo empírico de metáforas no plano da política brasileira, entre outros, do ex-presidente Lula e do Movimento dos Trabalhadores Rurais Sem Terra (MST).
} 
diferentes eventos, nos últimos quatro anos. Para o presente trabalho, utilizaremos exclusivamente o corpus integrado por textos coletados da seção de opinião do jornal Clarín, em específico a coluna dominical Humor político, do jornalista argentino Alejandro Borensztein, ${ }^{2}$ que passamos a denominar Corpus AleBores. Essa coluna, como observa o próprio autor, é publicada todo domingo há 12 anos.

A partir do contato inicial com o corpus, ainda enquanto leitores, pudemos perceber a riqueza lexical e a dificuldade que poderia representar a compreensão do sentido de determinadas unidades fraseológicas, de uso especializado no contexto da trama política. Por um lado, isso ocorreria pelo fato das diferentes áreas de especialidade convergentes e implicadas nos textos; por outro lado, pelo conhecimento sócio-histórico e cultural exigido, pela alusão a fatos que deveriam fazer parte da memória dos leitores, fundamentais para o estabelecimento das relações na construção dos sentidos. Cabe considerar, ainda, questões relacionadas à função comunicativa de determinadas ocorrências nos textos, isto é, à função pragmática implicada. Some-se a isso, no ato da leitura, a necessidade de reconhecimento e compreensão dessas unidades fraseológicas constituídas nos textos, isto é, o conhecimento mais estritamente linguístico, para reconhecimento e/ou identificação dos constituintes que formam as fraseologias, função necessária para compreensão da relação existente, muitas das vezes metafórica, entre os domínios vinculados por essas unidades fraseológicas.

Para exemplificar, em “También le pasó a Scioli en 2015. Se la dejaron abajo del arco y la tiró por arriba del travesaño" (BORENSZTEIN, 2018, nosso destaque). No âmbito da política argentina, Daniel Scioli foi o candidato à presidência argentina pelo Kirchnerismo, no final do segundo mandato de Cristina Kirchner. As fraseologias em destaque ilustram uma jogada de futebol em que alguém deixou a bola para outro jogador, na porta do gol ("se la dejaron abajo del arco"), ou seja, bastaria que o jogador chutasse para fazer o gol; contudo, chutou para fora, acima do travessão ("la tiró por arriba del travesaño"). Caberia a pergunta, aqui, qual a necessidade ou razão para utilizar a imagem de uma jogada de futebol para ilustrar uma situação do mundo da política? Tais unidades fraseológicas do domínio do futebol ("dejársela [la pelota/a

${ }^{2}$ Disponível em: https://www.clarin.com/autor/alejandro-borensztein.html. Acesso em: 10 ago. 2020. 
bola] abajo del arco" e "tirarla [la pelota/a bola] por arriba del travesaño") metaforizam, por meio de uma imagem mais concreta, uma situação mais abstrata do meio político, em que um candidato perdeu as eleições presidenciais, em circunstâncias que estariam bastante facilitadas, pois teriam deixado todo o caminho pronto para que fosse eleito. Em linguagem futebolística, deixaram na cara do gol, deram o gol servido, só faltava chutar para o gol.

Realizamos a exploração do Corpus AleBores em diversas direções, antes mesmo de encontrar o rumo que passou a conduzir a pesquisa, por meio da utilização das ferramentas WordList, KeyWords e Concord, do programa para análises lexicais WordSmith Tools (WST), versão 7,0 (SCOTT, 2016), em suas diferentes funcionalidades. Também recorremos ao suporte de recursos disponíveis on-line para consulta, a saber, o Corpus del Español (DAVIES, 2016, 2018), em sua versão dialetal, e o Sketch Engine (KILGARRIFF, 2019), utilizados fundamentalmente como corpora de consulta e contraste, para corroborar ou reformular hipóteses, a partir dos achados em nosso corpus. Como objeto de estudo tomamos, num primeiro momento, o gênero textual artigo de opinião, pelo prisma da Linguística de Corpus (LC). Num segundo momento, as Unidades Fraseológicas Especializadas (UFEs), caracterizadas pela presença de unidades léxicas que adquirem um valor especializado na área do futebol, enquanto candidatos a termos, mas utilizados metaforicamente em referência ao domínio da política. Ambos os trabalhos foram feitos na perspectiva das análises descritivas e empírico-dedutivas, com suporte tecnológico dos recursos anteriormente mencionados.

Por meio da extração e análise da lista de palavras-chave com a ferramenta KeyWords do WST, a pesquisa sobre o gênero possibilitou a identificação de características que apontam para a estabilidade e organização interna dos diferentes textos que compuseram o corpus. Algumas das características apontadas por Berber Sardinha (2009, p. $25-$ 26) foram observadas, como o fato de os gêneros serem social, cultural e historicamente definidos, sequenciados internamente e compostos por uma lexicogramática distinta. No entanto, o maior destaque foi a identificação de áreas temáticas que se mostraram salientes nos resultados, em especial, o domínio do futebol, pela recorrência de termos do meio futebolístico. 
A análise das palavras-chave extraídas dos corpora jornalísticos que compilamos especificamente para dois trabalhos, um apresentado no V Congresso Internacional de Fraseologia e Paremiologia, realizado na USP (NOVODVORSKI, 2018), ${ }^{3}$ e outro apresentado no XIV Encontro de Linguística de Corpus, realizados na UFRGS/Unisinos (NOVODVORSKI, 2017), ${ }^{4}$ a partir da filtragem dos resultados, possibilitou primeiro a identificação de diversos vocábulos da área do futebol, atestada pela frequência registrada por esses termos. Tudo se configurou como forte indício para pressupor que a representação do domínio futebolístico, nos textos que compõem o corpus, tenha uma relação direta na definição do domínio da política. Por meio das linhas de concordância, a Figura 1 ilustra uma aproximação para a análise contextualizada de um dos candidatos a termo (palo/palos).

FIGURA 1 - Linhas de concordância com palo/palos na ferramenta Concord

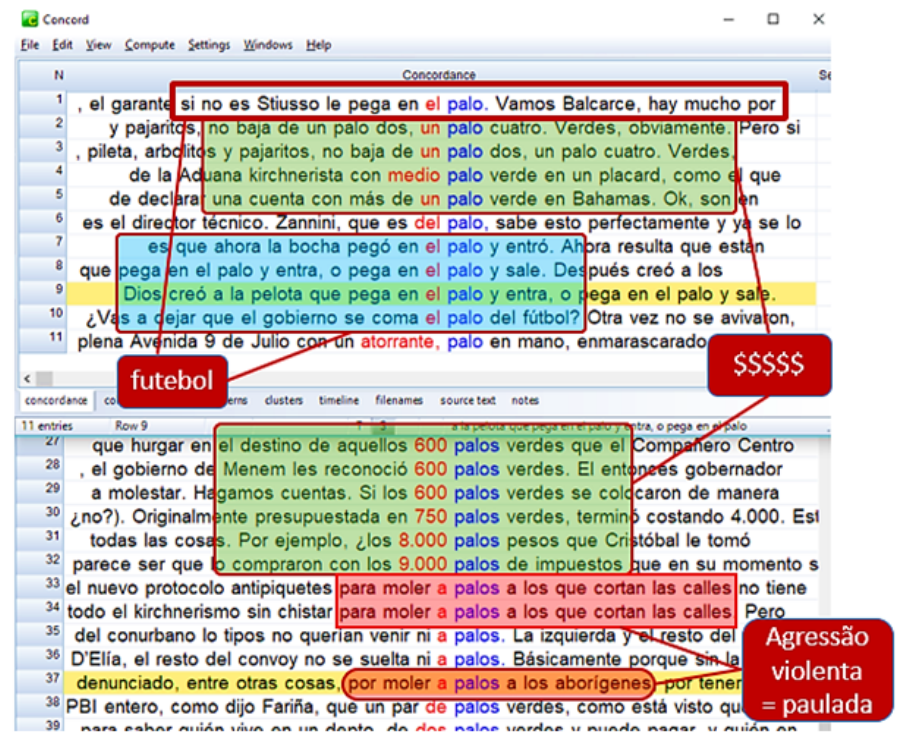

Fonte: A pesquisa (WST, versão 7.0)

${ }^{3}$ A política pela ótica do futebol: uma análise término-fraseológica em corpus jornalístico de humor político. Trabalho apresentado no V Congresso Internacional de Fraseologia e Paremiologia, em São Paulo, 2018.

${ }^{4}$ Humor político: o gênero pelo prisma da Linguística de Corpus.Trabalho apresentado no XIV ELC./IX EBRALC, em Porto Alegre, 2017. 
Como se observa na figura anterior, as linhas de concordância geradas a partir da busca pelo vocábulo palo revelam mais de um sentido: no âmbito do futebol, pegar en el palo equivale a bater na trave (linhas 01, 07-10); no campo da economia, palo(s) equivalem a milhão(ões), e palo(s) verde(s) a milhão(ões) de dólares; já em moler a palos temos a manifestação de um ato violento, correspondente a dar uma paulada. Além dessas, outras ocorrências como ni a palos, que equivale a de jeito nenhum, podem ser observadas na figura.

Das ocorrências registradas nessas linhas de concordância, tomamos a primeira linha, para ilustrar o aspecto de nossa proposta de análise: a metaforização da política pelo futebol. Pressupomos que há uma relação metafórica entre dois domínios ou áreas de conhecimento, em que as características de uma passam a ser assimiladas para a compreensão da outra. A frase "...si no es Stiuso le pega en el palo" (...se não for Stiuso, bate na trave) apresenta, por um lado, uma UFE formada por um termo da área do futebol, palo/trave, que, como já apontado, equivale a bater na trave. Para uma compreensão mais completa do fragmento, é necessário saber que Stiuso foi um agente secreto, dos serviços de inteligência, durante vários governos na Argentina. A suspeita, na época da publicação do texto jornalístico, era de que poderia haver alguma relação com o assassinato do procurador federal Alberto Nisman, que apareceu morto logo após denunciar Cristina Kirchner, presidenta na época, na véspera de sua declaração no Congresso Nacional. A relação metafórica existente entre os domínios fonte (futebol) e alvo (política) apontam que essa suspeita de envolvimento do agente Stiuso seria uma quase certeza, assim como uma bola que vai em direção ao gol e que, se não entrar, bateria na trave, o que seria quase um gol.

Como se observa, pela extração dos termos da área de futebol e pela identificação das UFEs, com auxílio das ferramentas do WST e dos recursos utilizados como corpora de consulta (DAVIES, 2016, 2018; KILGARRIFF, 2019), o passo seguinte correspondeu à identificação dos ambientes de ocorrência para completude da significação. Isto é, o sentido metafórico das UFEs é compreendido, quando acionada a perspectiva pragmática relacionada à referência ao meio político em questão, que demanda, também, um conhecimento contextual (social, histórico e cultural), além da percepção dos aspectos funcionais do texto em si, das funções comunicativas implicadas (CABRÉ, 1993). Desse 
modo, as três perspectivas se encontram interligadas, a da linguagem, do conhecimento e da comunicação.

A problematização que deriva de toda a contextualização anterior e que delineia, de algum modo, os rumos de nossa pesquisa e do texto aqui apresentado é: De que maneira acionamos, enquanto leitores e membros de uma comunidade sociocultural, as informações que são veiculadas nos textos, a tal ponto de conseguirmos compreender os sentidos construídos para o tratamento de questões políticas, por meio da linguagem futebolística? Em outras palavras, como ocorre a metaforização entre duas áreas de conhecimento, a política e o futebol, num corpus de textos de opinião?

Com base nas questões e tomando como ponto de partida Cabré (2002), formulamos nossa hipótese deste modo: existem aspectos cognitivos, linguísticos e pragmáticos entrelaçados e englobados por uma dimensão cultural mais ampla, acionada a partir de traços e vestígios identificados na leitura do texto. Isso equivale a dizer que o reconhecimento de determinadas marcas linguísticas nos textos, especificamente as UFEs, aciona nas lembranças do leitor o domínio do futebol, transferindo características dessa área, assimiladas na compreensão do domínio metaforizado, o campo da política. Considerando a perspectiva da comunicação, o autor dos textos promove a representação de um domínio por meio das características do outro, acarretando uma percepção mais acessível das questões políticas. Como o próprio autor aponta em diversas oportunidades "el fútbol lo explica mejor" (com o futebol dá para explicar melhor).

Dado o alcance da cultura do futebol, talvez pela plasticidade imagética que evocam determinadas jogadas e regras do jogo desse domínio e por estarem de algum modo no repertório popular, em especial em países como Argentina e Brasil, por considerar o âmbito concernente a este trabalho, expressões típicas desse domínio funcionam para metaforizar tanto situações mais corriqueiras do cotidiano quanto diversos âmbitos mais abstratos, não apenas o político. Assim, quando dizemos que alguém pisou na bola, ou que precisamos vestir a camisa da empresa ou instituição, ou que alguém precisa baixar a bola ou que levou cartão vermelho, sabemos que não estamos falando de futebol, mas por analogia nos referimos a um domínio mais abstrato, metaforizado. Com isso, muitas fraseologias características do futebol circulam na vida das pessoas, que recorrem à linguagem do futebol para falar de outras 
coisas. Para ilustrar, algumas frases típicas em espanhol foram tratadas e podem ser encontradas na matéria do jornal uruguaio El País, "Voces: El lenguaje de la cancha está presente en el de todos los días".

Desse modo, para além da descrição do corpus e dos procedimentos metodológicos envolvidos na pesquisa, nossos objetivos neste trabalho são (a) identificar e descrever termos e fraseologias especializadas, em cujos usos subjazem metáforas conceptuais, nos textos que perfazem o corpus de estudo, pelo cotejo dos sentidos promovidos nas áreas de especialidade relacionadas, e (b) analisar os aspectos referentes à metaforização entre os domínios da política e do futebol. Para tanto, apresentaremos no artigo um recorte dos resultados alcançados, em torno de duas Unidades Terminológicas (UT) referentes ao espaço destinado para a prática do futebol, a UFE "marcar la cancha" (marcar o campo de jogo) e a UT "canchereada", que pode ser traduzida como malandragem ou catimba, no meio futebolístico.

Por meio do quadro teórico-metodológico que será descrito a seguir e com o suporte das ferramentas, recursos e abordagem próprios da LC, buscaremos alcançar esses objetivos.

\section{Fundamentação teórica}

A presente pesquisa engloba as seguintes fontes bibliográficas, conforme cada uma das respectivas áreas teóricas: (1) Terminologia (CABRÉ, 1993, 2002, 2005; KRIEGER; SANTIAGO; CABRÉ, 2013); (2) Fraseologia Especializada (BEVILACQUA, 1998, 1999, 2004; CABRÉ; ESTOPÀ; LORENTE, 1996; ORENHA, 2009; ORENHA; CAMARGO, 2009); (3) Fraseologia (CORPAS PASTOR, 2010); (4) Metáfora (BERBER SARDINHA, 2007a, 2008, 2010; SPERANDIO, 2009, 2010, DEIGNAN, 2005, 2012; LAKOFF; JOHNSON, 1980); (5) Gramáticas Descritivas e Dicionários de Usos da língua espanhola e portuguesa (ANANÍA, 2005; BORBA, 2002; BOSQUE; DEMONTE, 1999; FONTANARROSA; SANZ, 1994; GOVERNATORI; LAROCCA, 2014; HOUAISS, 2009; MOLINER, 2008) e (6) Linguística de Corpus (BERBER SARDINHA, 2004, 2009; PARODI, 2008, 2010).

\footnotetext{
${ }^{5}$ Disponível em: https://www.ovaciondigital.com.uy/futbol/voces-lenguaje-canchapresente-todos-dias.html. Acesso em: 14 out. 2020.
} 
Para além dessas áreas, duas referências complementam este quadro, por cobrirem aspectos culturais, históricos e sociais da Argentina, em especial em torno da política, do futebol e da linguagem, escritos a partir da visão de dois jornalistas brasileiros com ampla experiência no país vizinho: Ariel Palacios e Guga Chacra. Ambos os livros foram publicados pela editora Contexto: Os hermanos e nós (PALACIOS; CHACRA, 2014) e Os argentinos (PALACIOS, 2015). É importante destacar, também, o lugar relevante que ocupam os diferentes programas computacionais, utilizados nas pesquisas desenvolvidas no âmbito da LC. Nesse sentido, também se incluem o software WST, ${ }^{6}$ versão 7,0 (SCOTT, 2016), as plataformas on-line Corpus del Español, nas versões dialetal ${ }^{7}$ e NOW $W^{8}$ - News on the Web (DAVIES, 2016, 2018), e Sketch Engine ${ }^{9}$ (KILGARRIFF, 2019).

Para situar a presente pesquisa no plano da Terminologia e, em particular, relacioná-la à especificidade do corpus de estudo, destacamos a delimitação feita por Cabré (1993) no tangente às peculiaridades das linguagens de especialidade, em contraponto à linguagem geral. A autora afirma que as linguagens especializadas se caracterizam em função da temática, dos falantes e das situações comunicativas, e que áreas como o comércio e o esporte também fazem parte da especialização, embora pudesse parecer que apenas temas científicos ou técnicos tivessem caráter de especialidade. Segundo a autora, dentre os aspectos linguísticos, funcionais e pragmáticos, são estes últimos os que possibilitam uma distinção mais clara entre as linguagens de especialidade e a língua comum, uma vez que permitem diferenciar termos de palavras. Assim, termos e palavras se diferenciam, considerando aspectos exclusivamente pragmáticos, a saber: pelos usuários, pelas situações de uso, pela temática e pelo tipo de discurso em que costumam aparecer.

Segundo Cabré (2005), o tema de uma comunicação é o ponto que determina o caráter de texto especializado. Para além das matérias científicas ou técnicas, âmbitos especializados de atividade como o esporte, dentre outros, produzem tipos de textos que se diferenciam dos textos considerados gerais, próprios de situações não profissionais. Em

\footnotetext{
${ }^{6}$ Disponível em: https://lexically.net/LexicalAnalysisSoftware/. Acesso em: 3 ago. 2020.

${ }^{7}$ Disponível em: https://www.corpusdelespanol.org/web-dial/. Acesso em: 10 ago. 2020.

${ }^{8}$ Disponível em: https://www.corpusdelespanol.org/now/. Acesso em: 10 ago. 2020.

${ }^{9}$ Disponível em: https://www.sketchengine.eu/. Acesso em: 30 jul. 2020.
} 
termos lexicais, continua a autora, os textos especializados são específicos pela terminologia e pela fraseologia utilizadas e, também, em função da semântica das unidades terminológicas que integram os textos. Assim, "cada unidade terminológica corresponde a um nó cognitivo dentro de um campo de especialidade, e o conjunto de nós cognitivos, conectados por relações específicas, constitui a representação conceptual de determinada especialidade" (CABRÉ, 2005, p. 25).

A esse respeito, Bevilacqua $(2004$, p. 43) complementa que o Núcleo Terminológico (NT), no reconhecimento das Unidades Fraseológicas Especializadas (UFEs), "deveria ser uma unidade nominal que corresponda a um nó cognitivo do âmbito tratado" no alcance do corpus textual da pesquisa. Esta consideração é relevante, por possibilitar o tratamento das UFEs como unidades de representação e transmissão de conhecimento especializado. Desse modo, continua Bevilacqua (2004, p. 11), "é possível investigar como transmitimos e adquirimos conhecimento especializado, por meio de outras unidades linguísticas, que não são exclusivamente os termos". Estas últimas observações respaldam plenamente os objetivos que nos propomos alcançar na presente pesquisa, tal como observado na Introdução. Como já apontado, pressupomos que o reconhecimento de determinados agrupamentos lexicais nos textos, especificamente as UFEs, ativam no leitor o domínio do futebol. Deste domínio são transferidas características, que passam a ser assimiladas para a compreensão do outro domínio, que é metaforizado, o campo da política.

Cabré (2002) reforça que o caráter específico das unidades terminológicas reside em aspectos pragmáticos e que as significações são resultado de uma negociação entre especialistas, produzida no âmbito de um discurso especializado, por meio da realização de predicações que definem os significados das unidades. Com isso, a autora propõe uma teoria que possibilita um tratamento multidimensional dos termos, que contempla de modo integrado aspectos cognitivos, linguísticos, semióticos e comunicativos. Desse modo, o termo, enquanto unidade, é formado por uma dimensão semiótica e linguística, por outra cognitiva e por uma terceira vertente comunicativa.

Por outro lado, é importante a característica recursiva e dinâmica dos termos, que podem se deslocar de uma área de especialidade para outra, assim como as unidades do léxico comum passam para o léxico especializado, respectivamente banalização e teminologização (CABRÉ, 
2005). Em entrevista (KRIEGER; SANTIAGO; CABRÉ, 2013), a pesquisadora observa que tem tratado a "terminologicidade" como um valor associado às unidades do léxico, a partir de uma concepção de termo enquanto unidade do léxico que ativa um sentido preciso, num contexto sociocomunicativo específico. Destacamos, portanto, que "os termos não são unidades diferentes das unidades do léxico, e sim unidades do léxico que adquirem características específicas em seu uso discursivo" (KRIEGER; SANTIAGO; CABRÉ, 2013, p. 331). A autora ainda observa que o objetivo da terminologia aplicada consiste tanto na compilação das unidades de valor terminológico, sobre uma temática e situação determinadas, quanto no estabelecimento das características, conforme essa situação.

Em se tratando da compilação e extração (semi)automática de unidades de valor terminológico, é importante recuperar e destacar as dificuldades encontradas e alguns dos critérios apontados, no trabalho empírico e seminal de Cabré, Estopà; Lorente (1996), no que diz respeito às UFEs. Em particular, chamamos a atenção para especificidade temática, quanto à determinação de uma unidade ser ou não um termo, e à delimitação do segmento formal que compõe uma unidade terminológica, no caso de unidades sintagmáticas. Por meio de uma ampla experimentação e centradas no estudo das unidades terminológicas polilexemáticas (UTP), em contraposição às UFEs e, no intuito de poder distinguir entre termos sintagmáticos e construções fraseológicas especializadas, as autoras assumem ser resultante essa distinção da aplicação de critérios como a categoria gramatical, a estrutura interna, a frequência, o grau de fixação e a variação dos componentes. Nesse ponto, destacam a regularidade observada na condição de termo dos núcleos dos sintagmas nominais, no caso das UTP, e da condição de termo dos complementos, nos sintagmas verbais, no caso das UFEs. Ainda reforçam não acreditarem na existência de termos nem fraseologia especializada de modo abstrato, uma vez que sempre adquirirão o valor de UT, UTP ou UFE, no âmbito de uma área de especialidade. Estes últimos apontamentos guardam relação direta com a proposta de nossa pesquisa.

Ressaltando o caráter cognitivo e comunicativo da proposta teórica de Cabré, a Teoria Comunicativa da Terminologia (TCT), Bevilacqua (2004, p. 10) destaca a importância do tratamento da fraseologia especializada no campo da Terminologia e afirma que, assim como as Unidades Terminológicas (UTs), também as UFEs "podem 
ser consideradas um objeto de estudo poliédrico, multifuncional e multidimensional". Dessa maneira, a autora aponta a possibilidade de análise das UFEs, a saber: (1) pela perspectiva cognitiva, enquanto "unidades transmissoras de conhecimento especializado", que no contexto dessa abordagem teórica são denominadas Unidades de Conhecimento Especializado (UCE); (2) enquanto unidades que ocorrem em situações especializadas, denominadas Unidades de Comunicação Especializada (UNICOME); e (3) pela perspectiva da linguagem (abordagem também adotada nesta pesquisa), em que o tratamento das UFEs implica a percepção, descrição e análise, conforme a gramática da língua em questão e a partir da materialidade linguística, isto é, a utilização de critérios morfológicos, sintáticos, semânticos e pragmáticos, na análise de um corpus de textos produzidos por especialistas, em torno de temáticas específicas e em contextos de uso real da língua. Considerando o uso especializado, são denominadas Unidades de Significação Especializada (USE).

Bevilacqua (1998, 1999, 2004) define as UFEs como unidades sintagmáticas, integradas por um termo, com determinado grau de fixação e de frequência num corpus ou domínio especializado. A pesquisadora (2004) propôs, especificamente em sua tese, as unidades fraseológicas formadas por um núcleo eventivo, que denominou unidades fraseológicas especializadas eventivas (UFE eventivas). Essas unidades sintagmáticas são formadas, conforme suas propriedades, por um ou mais termos, que constituem o Núcleo Terminológico (NT), e um Núcleo Eventivo (NE), que é realizado textualmente por um verbo, um nome deverbal ou um particípio. Orenha (2009) e Orenha e Camargo (2009) analisam termos, colocações e colocações especializadas, por meio da extração de UFEs com subsídios da LC, em corpora paralelos bidirecionais e comparáveis, no par linguístico inglês/português, envolvendo traduções juramentadas e não juramentadas, de documentos de contratos e estatutos sociais. Considerando aspectos referentes aos profissionais da Tradução, as autoras apontam o valor de inclusão em obras terminográficas dos padrões de UFEs encontradas.

Corpas Pastor (2010) também destaca que os fatores de frequência de ocorrência e de coocorrência são elementos que compõem e possibilitam a identificação das UFs, além da institucionalização, a estabilidade, a idiomaticidade e a variação que tais unidades apresentam em diferente grau. Essa autora define a UF como uma combinação estável 
de, pelo menos, duas palavras, cujo limite superior será o sintagma ou a oração composta e apresentará como traços inerentes a fixação ou a idiomaticidade por si mesmas, ou uma combinação de ambos os critérios (CORPAS PASTOR, 2010, p. 126).

Acerca da consideração do fator frequência e, em particular, pelo fato de definir as UFEs como "unidades que adquirem valor especializado pelo e no texto em que são utilizadas" (BEVILACQUA, 2004, p. 44), a autora destaca que, na seleção das unidades no corpus, há outros fatores que já seriam suficientes para "mostrar o valor especializado das unidades extraídas" (idem). Ou seja, o critério frequência não deveria ser conclusivo para a seleção das UFEs. Essa observação é de vital importância para nossa pesquisa, uma vez que, a depender da extensão do corpus de estudo, itens de baixa frequência ou que reportam uma única ocorrência (hapax legomena) poderiam ser desconsiderados, mesmo apresentando caráter especializado. Desse modo, assumimos que a frequência será observada, mas não como fator determinante para a constatação de que uma unidade seja considerada UFE, como será descrito na seção de Corpus e Metodologia.

A taxonomia proposta (CORPAS PASTOR, 2010, p. 127-136) para classificação das UFs define um primeiro nível de estruturação em três esferas: (1) as colocações, fixadas pelo uso, com algum grau de restrição combinatória; (2) as locuções, fixadas no sistema; e (3) os enunciados fraseológicos (parêmias e fórmulas), fixados na fala, formam parte do acervo sociocultural da comunidade do falante. Estes últimos se diferenciam das colocações e locuções pelo fato de chegarem a formar enunciados completos em si mesmos e a realizarem atos de fala, independente da combinação com outros elementos no discurso.

Já encerrando esta breve introdução e complementando o enquadramento teórico da pesquisa proposta, enfocamos o estudo da Metáfora pela visão cognitiva, como um recurso natural e intrínseco ao ser humano, por meio do qual se busca entender o mundo, processando mentalmente conceitos abstratos, partindo de conceitos concretos. Nesse sentido, mais do que se caracterizar como um traço da linguagem, a metáfora estabelece relações entre dois conceitos diferentes, que se unem por associação para compreendermos um deles a partir das características do outro. Portanto, "a essência da metáfora é entender e experimentar um tipo de coisa em termos de outra" (LAKOFF; JOHNSON, 1980, p. 41). Esses autores chegaram à conclusão de que nossa vida cotidiana está 
impregnada de metáforas, e que nosso sistema conceptual ordinário, em torno do qual pensamos e atuamos, é de natureza metafórica. Pelo fato de lidarem com conceitos e de estabelecerem uma conexão entre duas áreas ou domínios semânticos, um concreto e outro abstrato, recebeu o nome de Metáfora Conceptual.

Deignan (2005, p. 14-29) destaca pontos que são essenciais para nossa pesquisa, quanto à estruturação do pensamento por meio das metáforas e com relação ao estudo de padrões pelo viés empírico que proporciona a LC. A autora observa que, geralmente, pesquisadores buscam metáforas conceptuais através da linguagem, na tentativa de encontrar padrões em frases e palavras, como evidência de metáforas conceptuais subjacentes. Desse modo, estabelece uma distinção fundamental entre metáforas linguísticas e metáforas conceptuais, afirmando que as metáforas linguísticas realizam as metáforas conceptuais, mas que isso não deve conduzir à interpretação de que a Teoria da Metáfora Conceptual tenha sido desenvolvida para explicar padrões linguísticos, pois o percurso é exatamente o inverso (DEIGNAN, 2012). O sentido de uma metáfora linguística é descrito em termos de veículo, que é o significado literal de uma palavra ou frase no domínio fonte (concreto), e tópico, que é o significado de uma palavra ou frase no domínio alvo (abstrato). Retomando o exemplo da Introdução deste artigo, "Si no es Stiusso le pega en el palo", temos como veículo a UFE "le pega en el palo" (bater na trave), do domínio fonte e mais concreto do futebol, e como tópico "Si no es Stiusso" (Se não for Stiusso, um agente de inteligência argentino), do domínio alvo e mais abstrato da política. Essa metáfora linguística realiza a metáfora conceptual mais genérica, em que POLÍTICA É FUTEBOL, grafada em caixa alta como convenção geral.

Aqui cabe uma breve observação quanto ao uso dos vocábulos realizar ou realização, que adquirem um sentido técnico, especializado, a partir dos estudos sistêmico-funcionais hallidayanos. Conforme a Linguística Sistêmico-Funcional, a linguagem verbal é um sistema sociossemiótico estratificado, que resulta da formulação e troca de significados. Os contextos mais amplos de cultura e de situação se realizam nos estratos da linguagem, passando pelos níveis da semântica do discurso, na construção de significados, e pela organização no estrato lexicogramatical, alcançando o nível da expressão, por meio de um texto escrito ou oral, realizado no plano gráfico ou fonético. Nesse sentido, 
contexto sociocultural e linguagem são indissociáveis, uma vez que estão imbricados numa relação de mútua realização.

Assim como afirma Deignan (2005) e vários outros autores, as metáforas linguísticas são o principal tipo de evidência dada para a existência de metáforas conceptuais, atestada pela frequência de ocorrência. Talvez o principal tipo de evidência resida no potencial de as metáforas conceptuais revelarem a sistematicidade do léxico, no sentido de motivarem uma significativa quantidade de metáforas linguísticas, mapeáveis por meio de relações no interior ou entre campos lexicais. Além desse tipo de evidência, também a possibilidade tanto de criação como de compreensão de novas metáforas, por analogia a metáforas convencionais já existentes, entre determinados domínios (DEIGNAN, 2012). Por outro lado, o fato de a LC se ocupar da exploração de corpora de textos autênticos, em detrimento de frases inventadas ou descontextualizadas, corrobora a probabilidade de ocorrência das metáforas linguísticas em usos linguísticos reais. Num corpus de estudo, a autora menciona ter analisado palavras-chave referentes à temática de corrida de cavalos e jogos de apostas, em que os dados do corpus mostraram, por meio das colocações e linhas de concordância, frequentes usos metafóricos a respeito de campanhas políticas em inglês (DEIGNAN, 2005). É também relevante para nosso trabalho a observação feita por Deignan (2005), quando aponta ser provável que as pessoas, às vezes, explorem deliberadamente mapeamentos metafóricos com o propósito de criar efeitos de humor ou estilísticos.

Berber Sardinha (2007a, 2007b, 2008, 2009, 2010) aponta que o estudo da metáfora conceptual, tal como descrita em termos cognitivos, oferece grandes desafios e oportunidades para a LC, se considerado que, pelo fato de ser um fenômeno corriqueiro, da vida cotidiana, deverá estar presente nos corpora que compilamos. Nesse ponto, o autor se questiona acerca dos procedimentos necessários para exploração de corpus e extração dessas metáforas, por meio das ferramentas da LC, uma vez que depreendemos o sentido das palavras a partir do uso e que, nesse aspecto, a LC tem oferecido evidências abundantes e consistentes quanto a isso. Por outro lado, Berber Sardinha (2009, p. 43) destaca que, sendo a metáfora conceptual um fenômeno cognitivo, sua exploração por meio da LC seria um modo de "conseguir inferir o processamento mental a partir das instâncias de uso" e que essa já poderia se configurar 
como uma resposta, ainda que parcial, à crítica de que a LC teria pouca capacidade de teorizar a respeito da linguagem.

No âmbito da pesquisa nacional, em português brasileiro, são diversos os trabalhos que guardam relação direta com nossa pesquisa e que servem de motivação como pontos de contraste e de comparação, tanto pelo viés empírico da exploração de metáforas conceptuais à luz da LC, quanto pelo uso de corpora jornalísticos. A abordagem das questões culturais implicadas também é relevante, por se tratar de países vizinhos, Brasil e Argentina, com histórias e relações sócio-políticas muito próximas. Como exemplo, Berber Sardinha (2007b) indica que as metáforas são culturais, portanto, relacionadas a determinada cultura, civilização ou ideologia, não havendo, nesse sentido, verdades absolutas para a Teoria da Metáfora Conceptual. Nesse texto (BERBER SARDINHA, 2007b, p. 168) e em referência às metáforas do presidente Lula à época, o autor destaca que ao dizer que "vamos vestir a camisa de um setor da sociedade, estamos conceituando e entendendo a sociedade como um esporte, as pessoas como jogadoras, outros grupos como adversários, a convivência como uma partida e a conduta desejada como as regras do jogo, observadas por um árbitro". Como bem observa o autor, todos esses mapeamentos ficam subentendidos pelo campo conceitual do jogo em si, pelo fato de haver um conhecimento compartilhado do que seja uma partida, talvez de futebol, e das partes implicadas. Tudo isso possibilita o entendimento da expressão como metáfora.

Também destacamos Berber Sardinha (2007a), que descreve diferentes métodos e analisa as metáforas da imprensa de modo geral, em corpus do jornal Folha de São Paulo, e as metáforas de um jornalista em particular, Joelmir Beting. As metáforas do ex-presidente Lula também se fazem presentes em outras publicações de Berber Sardinha (2008, 2010), em relação à conquista e ao desenvolvimento, respectivamente. Para tornar mais ilustrativas as inferências resultantes dos mapeamentos, denominadas desdobramentos na teoria, o pesquisador apresenta, no caso do jogo em equipe "Se a partida é o comércio exterior, a vitória seria o superávit nas contas dos países do bloco econômico. Uma derrota, por outro lado, seria um déficit nas contas" (BERBER SARDINHA, 2008, p. 99). Ainda mencionamos, aqui, as pesquisas de Sperandio (2009, 2010), em que a autora analisa, no primeiro trabalho, usos metafóricos em discursos do ex-presidente Lula, relacionados ao Programa Fome Zero e, no segundo, metáforas com relação ao Movimento dos Sem-Terra 
(MST), em duas reportagens da revista brasileira Veja e da estadunidense Newsweek, ainda que sem lançar mão dos recursos e ferramentas características da LC.

Entendemos que, para além de todas as motivações e justificativas já elencadas, a possibilidade de buscar respostas quanto ao eventual caráter teórico da LC, como auxílio à compreensão do modo como metaforizamos e compreendemos as metáforas conceptuais que subjazem às metáforas linguísticas, mapeáveis a partir da identificação e descrição das UFEs com auxílio das ferramentas do WST, é um forte indício tanto do mérito dos trabalhos que recorrem à LC para a realização de pesquisas empírico-descritivas quanto do lugar já consagrado da LC. Em nossa opinião, é tão descabido atribuir um valor exclusivamente metodológico à LC quanto ainda continuar duvidando acerca do lugar de prestígio que já ocupa na área da Linguística, tanto teórico-descritiva quanto aplicada. Formulamos nossas hipóteses, a partir da ótica da LC, que corroboramos, refutamos ou reformulamos, com base na indagação de corpora; hipóteses que podem derivar, ainda, na formulação ou constatação de teorias.

$\mathrm{Na}$ próxima seção, descrevemos tanto o corpus quanto os procedimentos implicados neste trabalho.

\section{Corpus e Metodologia}

O corpus de estudo de nossa pesquisa, que denominamos Corpus AleBores, está formado por grande parte dos textos publicados na seção de opinião Humor Político, do jornal argentino Clarín, escritos em espanhol rio-platense pelo colunista e arquiteto Alejandro Borensztein, especificamente, por todos os textos aos quais foi possível ter acesso, no período entre 2009 e 2019. Tal como é mencionado em encontro on-line com o autor (29/05/2020), no âmbito do Ciclo de Diálogos com Clarín, ${ }^{10}$ a coluna começou a ser escrita em 2007, completando em 2020 treze anos de publicações dominicais. Como aponta o autor, sua verdadeira formação universitária e profissional é em Arquitetura, por ter feito a carreira acadêmica, de graduação e pós-graduação, nessa área. A respeito do ofício de escrita semanal de um texto a ser publicado num dos jornais de maior circulação no país, Borensztein observa que surgiu de modo

\footnotetext{
${ }^{10}$ Informações disponíveis em: https:/www.clarin.com/dialogos/entrevista_Alejandro_ Borensztein. Acesso em: 20 jun. 2020.
} 
casual e que se conecta com uma experiência profissional prévia, na televisão, de aproximadamente 30 anos atrás. Com seu irmão Sebastián, reconhecido cineasta argentino, autor de filmes como La suerte está echada e Un cuento chino, entre outros, Alejandro escrevia para um programa televisivo, por indicação de seu pai, Tato Bores, humorista político renomado.

O colunista destaca, então, que o processo de escrita foi uma grande lição, porque nunca foi algo planificado em sua vida, assim como todas as demais atividades profissionais, na Arquitetura e na Televisão, para as quais sempre foi mais esquemático e ordenado. Lembra, também, que a demanda de escrita de uma matéria para ser publicada, todos os domingos, ocupando página inteira do Clarín, surgiu há treze anos em função de uma nota encaminhada a esse jornal, que seria uma carta de leitor e acabou sendo publicada e acarretando esse compromisso desde então, devido ao sucesso que teve.

$\mathrm{Na}$ reportagem, Alejandro Borensztein responde questões feitas pelos assinantes do jornal e fala a respeito dos principais personagens da coluna Humor Político, presidente atual ou ex-presidentes ou candidatos à presidência na Argentina, que os leitores aprenderam a acompanhar $\mathrm{e}$ reconhecer semanalmente, a partir destes nomes: Tío Alberto (Alberto Fernández, atual presidente); Mauri ou el Gato (Mauricio Macri), ExElla, la Jefa, la Arquitecta Egipcia, Reina Hotelera, além de outros nomes (Cristina Kirchner), Compañero Lancha (Scioli, ex-candidato à presidência) e Compañero Centro Cultural, Compañero Torneo Clausura (Néstor Kirchner). Além desses nomes, sobre muitos outros é explicada a origem e evolução, como Campeonato del Pelotudo del año, el Club de los Malos, que fazem referência a manifestações ou atitudes de políticos em particular, ou de posicionamentos de partidos políticos, que muitas vezes resultam curiosas ou polêmicas e que motivam a escrita humorística da coluna dominical.

Também é feita uma alusão às metáforas presentes na escrita do colunista, ponto essencial no âmbito deste trabalho. A Figura 2 ilustra ocorrências no corpus que corroboram o papel das metáforas na relação entre política e futebol: 
FIGURA 2 - Linhas de concordância no corpus de estudo com metáfora

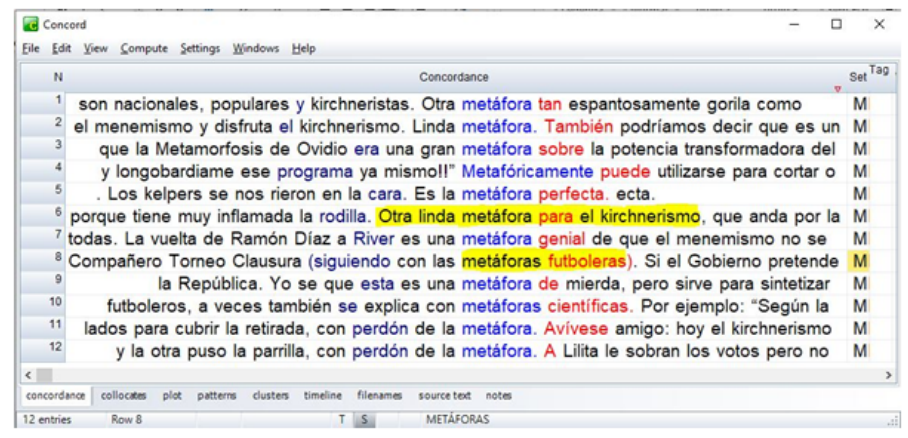

Fonte: WordSmith Tools (SCOTT, 2016)

Dentre os principais aspectos da tipologia do corpus de estudo, destacamos: (a) modo escrito, em formato eletrônico; (b) contemporâneo e diacrônico, de 2009 a 2019; (c) de seleção definida pelo gênero (seção de opinião: humor político) e extensão mensurada em textos (mais de 400) e em itens (mais de 450 mil palavras); (d) de conteúdo especializado, marcado pelo campo socioprofissional (política); (e) monolíngue, na língua espanhola, em sua variedade rio-platense; (f) de autoria única, em língua nativa; e (g) para finalidade de pesquisa. A integralidade dos textos que compõem o corpus foi mantida. $\mathrm{O}$ máximo de textos publicados anualmente foi de 47. O número menor de textos coletados em alguns anos deriva de sua indisponibilidade na página do jornal. É oportuno destacar que o corpus foi compilado exclusivamente para fins de pesquisa, sem nenhum propósito comercial nem de disponibilização ou reprodução parcial ou integral. Os fragmentos presentes nas análises dos resultados correspondem a pequenos trechos em que são identificadas as ocorrências pertinentes para a pesquisa, que podem chegar até o nível de um parágrafo, no máximo. Para ter acesso sem registro ao jornal Clarín, existe uma permissão limitada a um quantitativo de textos por mês, que depende do conteúdo consumido pelo usuário, conforme consta nos termos e condições publicados no site do jornal. É necessário estar registrado, para ter acesso a um conteúdo maior de textos, e ser assinante, para ter recursos disponíveis no jornal como ouvir a leitura de notícias, copiar conteúdo, fazer comentários ou imprimir, entre outros. Embora a autoria única do corpus possa, certamente, trazer questões estilísticas ou a visão de um único indivíduo (objetos que não fazem parte deste trabalho), 
o contraste dos resultados por meio de consulta aos corpora disponíveis on-line (DAVIES; 2016, 2018; KILGARRIFF, 2019) possibilita atestar, pela frequência, a recorrência do uso de determinadas UFEs encontradas e/ou de metáforas linguísticas que realizam metáforas conceptuais, sendo mais características de determinados países, como poderá ser observado na próxima seção.

A Tabela 1 apresenta a extensão do corpus de estudo e sua distribuição nos diferentes anos de publicação.

TABELA 1 - Extensão do Corpus AleBores

\begin{tabular}{c|c|c|c|c}
\hline Ano & $\boldsymbol{N}^{\boldsymbol{o}}$ textos & Tokens & Types & T/T ratio \\
\hline $2009-2010$ & 08 & 9.698 & 2.824 & 29,12 \\
\hline 2011 & 41 & 37.774 & 7.508 & 19,88 \\
\hline 2012 & 37 & 35.954 & 7.262 & 20,20 \\
\hline 2013 & 47 & 52.658 & 9.227 & 17,52 \\
\hline 2014 & 47 & 52.022 & 9.215 & 17,71 \\
\hline 2015 & 47 & 52.363 & 8.445 & 16,13 \\
\hline 2016 & 42 & 46.529 & 8.426 & 18,11 \\
\hline 2017 & 44 & 57.300 & 9.522 & 16,62 \\
\hline 2018 & 47 & 62.471 & 9.785 & 15,66 \\
\hline 2019 & 46 & 60.032 & 9.370 & 15,61 \\
\hline TOTAIS & $\mathbf{4 0 6}$ & $\mathbf{4 6 6 . 8 0 0}$ & $\mathbf{3 1 . 7 5 9}$ & $\mathbf{6 , 8 0}$ \\
\hline
\end{tabular}

Fonte: A pesquisa

A seguinte enumeração de itens procura descrever, primeiro, a sequência de etapas mais gerais desenvolvidas no âmbito desta pesquisa. Em segundo lugar, adentramos de modo mais específico nos procedimentos envolvidos na compilação, preparação e armazenamento do corpus de estudo, para seu tratamento com as ferramentas utilizadas no auxílio à extração de dados, à descrição e às correspondentes análises.

1) Planejamento das características do corpus compilado, considerando fatores como extensão e representatividade;

2) Definição de critérios e códigos para compilação e armazenamento do corpus de estudo; 
3) Compilação, preparação e armazenamento do corpus;

4) Anotação de metadados e elementos histórico-contextuais referentes aos textos compilados para constituição do corpus;

5) Levantamento dos dados estatísticos do corpus;

6) Extração das palavras-chave do corpus de estudo, relacionadas aos diferentes campos lexicais e semânticos do futebol e da política;

7) Identificação e extração dos candidatos a termo, no domínio do futebol;

8) Identificação, extração e descrição das unidades fraseológicas especializadas do âmbito do futebol, na metaforização do domínio da política, a partir da análise das linhas de concordância e dos subsídios (colocados, clusters) que oferecem as ferramentas e utilitários dos programas computacionais;

9) Análise e descrição das relações metafóricas, à luz das UFEs extraídas, entre os domínios do futebol e da política;

10) Classificação e sistematização dos resultados, a partir da consulta tanto a dicionários gerais e especializados das línguas espanhola e portuguesa em uso, quanto a recursos on-line de consulta, como o Corpus del Español e do Português (DAVIES, 2016, 2018) e Sketch Engine (KILGARRIFF, 2019).

Os procedimentos envolvidos na compilação, preparação e armazenamento do Corpus AleBores partiram do acesso à página do colunista. ${ }^{11}$ Abrimos individualmente cada uma das publicações disponíveis de Humor Político, selecionamos o texto, para copiar e colar seu conteúdo integral em arquivos individuais em formato TXT. Esse foi o procedimento que se mostrou mais eficaz, para evitar que fossem transportados ao corpus informações relacionadas a imagens ou links, que demandariam uma posterior limpeza dos arquivos.

Para a nomeação de cada texto do corpus, utilizamos uma sequência de 8 números, seguindo a sequência conforme data de publicação: ano, mês, dia (exemplo, 20141012). Os títulos dos textos foram etiquetados por meio das $\operatorname{tags}<\mathrm{T}>$ e $</ \mathrm{T}>$, no intuito de separar título de conteúdo textual e para a recuperação de informações, durante as buscas com os programas do WST. Os textos foram armazenados em pastas no Explorador de arquivos do Windows, organizados por anos de

${ }^{11}$ Disponível em: https://www.clarin.com/autor/alejandro-borensztein.html. Acesso em: 17 jun. 2020. 
publicação e compartilhados no OneDrive entre os autores da pesquisa, para acompanhamento e trabalho conjunto.

Com o corpus compilado, preparado e armazenado, o passo seguinte foi a extração dos dados quantitativos mais gerais, primeiro, por meio da ferramenta WordList, como apresentado na Tabela 1. Geramos listas de palavras para cada um dos subcorpora, a partir dos anos de publicações coletadas e, também, uma lista de palavras com corpus geral. Para extração das palavras-chave, por meio da ferramenta KeyWords, contrastamos a lista de palavras do Corpus AleBores, nosso corpus de estudo, com a lista de palavras de um corpus de referência compilado no âmbito de uma pesquisa de Iniciação Científica que orientamos (ALVES, 2013). Esse corpus é formado pelas publicações de 6 seis Congresos Internacionales de la Lengua Española (1992 - 2010), portanto, correspondente ao gênero de escrita acadêmica. O corpus de referência possui uma extensão de 2.834.385 tokens e 95.649 types, em 813 textos, representando em torno de 6 vezes mais do que o tamanho do corpus de estudo, em extensão pelo número de palavras. Conforme a literatura da LC (BERBER SARDINHA, 2004, 2009), o corpus de referência deve ser em extensão, no mínimo, cinco vezes maior do que o corpus de estudo. A diferença quanto ao gênero do corpus de referência busca, fundamentalmente, trazer à tona o que é proeminente no corpus de estudo, no intuito de poder apontar para temáticas e campos lexicais em destaque. Um corpus de referência com características similares às do corpus de estudo, em termos de extensão, autoria ou gênero, tenderia a neutralizar os resultados. Considerando a representatividade do corpus de estudo, situado no âmbito da trama política argentina e registrada em tom humorístico numa coluna jornalística, o corpus de referência de escrita acadêmica utilizado, por sua extensão e diferença temática, é um ponto de comparação que se ajustou às necessidades da pesquisa.

Realizamos diferentes tipos de testes, aplicados à extração de palavras-chave, por meio de diversos ajustes na configuração da ferramenta KeyWords, especificamente no $p=$ value, de $\mathrm{p}=0,05$ a $\mathrm{p}=0,0000001$, e no max. wanted (8.500) e min. freq. (3), no intuito de conferir as respectivas diferenças e de corroborar a maior ou menor presença dos itens que formariam uma lista de candidatos a termo, no domínio do futebol. Desse modo, obtivemos diferentes resultados, que variaram entre 226 e 8.161 vocábulos. Após leitura, análise e limpeza dessas primeiras listas (exclusão de todos os vocábulos não pertencentes 
ao domínio do futebol) e, paralelamente, pela comparação com os resultados da lista de palavras do corpus de estudo geral, pouco mais de 31 mil tokens, foi possível constatar que as listas de palavras-chave extraídas por meio da ferramenta KeyWords, independentemente dos diversos tipos de ajustes realizados na configuração, não reportava a totalidade dos vocábulos candidatos a termo. Isto é, itens com baixa frequência de ocorrência no corpus de estudo ou cujos resultados teriam sido neutralizados pelo corpus de referência, simplesmente não foram identificados pela ferramenta, apesar de não deixarem de estar presentes no corpus e de fazerem parte do objeto de estudo desta pesquisa. Nesse sentido, decidimos realizar a análise, limpeza e extração dos candidatos a termo diretamente da lista de palavras gerada com a ferramenta WordList. Com a ferramenta KeyWords, obtivemos no resultado mais produtivo 226 palavras-chave, que resultaram em 134 candidatos a termo, após lematização. Já a análise com a ferramenta WordList possibilitou a extração de 337 candidatos a termo, após realização dos processos de limpeza e lematização, como se observa na Figura 3, que ilustra a alta frequência de vocábulos do domínio do futebol no corpus.

FIGURA 3 - Lista de candidatos a termo lematizada

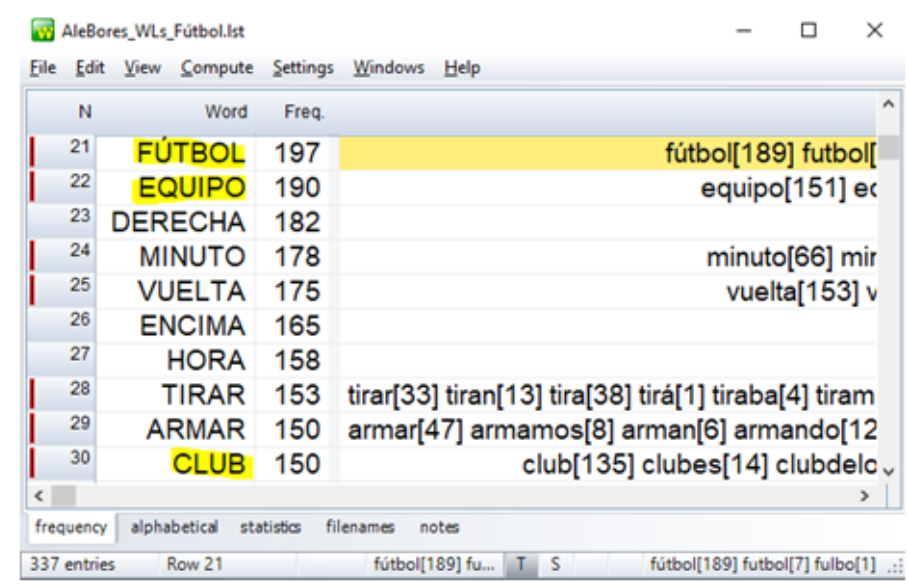

Fonte: WordSmith Tools (SCOTT, 2016)

Foi oportuno apreciar, durante os diversos testes, que muitos itens de ocorrência 1, hapax legomena, fazem parte da temática em estudo e apresentam não apenas combinatórias léxicas, como também 
UFEs e processos de metaforização, relevantes para esta investigação. Assim, salvamos uma lista com os hapax do Corpus AleBores que, após o procedimento de lematização, ficaram reduzidos a 19, entre os candidatos a termo. É relevante destacar, ainda, que os nomes próprios e apelidos de clubes, jogadores, técnicos, estádios, torneios e associações de futebol, entre outros, foram salvos em lista separada, uma vez que não serão analisados como base, na formação de combinatórias léxicas ou de UFEs. A lista com nomes próprios do âmbito do futebol registrou 70 vocábulos, alguns com frequência elevada, a saber: Boca (213), River (86), Bombonera (46), Libertadores (33) e Messi (23).

A proposta de organização dos candidatos a termos do domínio do futebol em campos lexicais e semânticos, a partir dos resultados das palavras-chave e, na sequência, tomando por base a lista de palavras resultante após limpeza e lematização, foi um procedimento prévio e auxiliar à identificação das UFEs. Pensamos inicialmente em 10 campos, para organização e classificação dos resultados, após análise dos vocábulos e identificação dos candidatos a termos. Nessa etapa, a ferramenta Concord é de vital importância, como pode ser observado na Figura 4. A partir da busca por um item lexical específico, neste caso cancha (f 79 / UT 70), uma vez identificado como candidato a termo, geramos as linhas de concordância que trazem tantas linhas quantas ocorrências do termo houver no corpus.

FIGURA 4 - Linhas de concordância com cancha

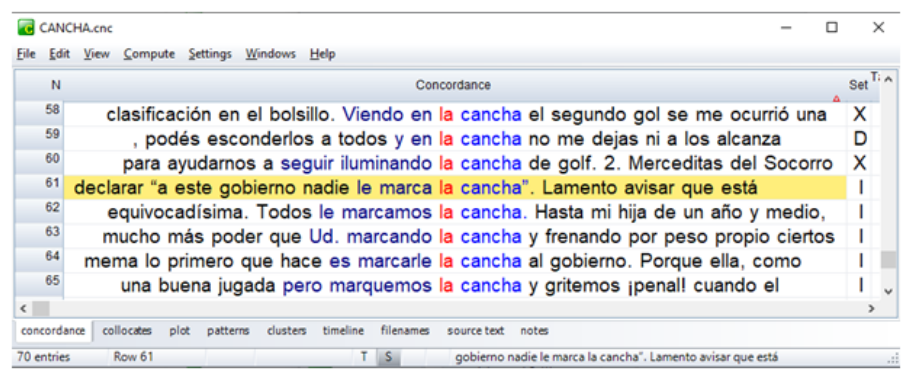

Fonte: WordSmith Tools (SCOTT, 2016)

É pela análise das ocorrências dos candidatos a termo em contexto, por meio das linhas de concordância, que se pode chegar à constatação de que um item lexical funciona como um termo, em determinado ambiente textual. Assim, a partir de cada um dos itens lexicais da lista, foram 
geradas as linhas de concordância correspondentes, os resultados foram analisados e os arquivos foram salvos em pasta específica, identificados pelo nome do item de busca. Na ferramenta Concord, utilizamos a coluna Set como um recurso auxiliar na classificação e organização dos resultados (ver figura anterior). Por meio da inserção de um caractere (letra ou número), agrupamos os padrões identificados e separamos as ocorrências que não correspondessem a nosso objeto de estudo, quando os domínios implicados não fossem o do futebol e da política.

Procedimento análogo adotamos para a extração das combinatórias léxicas e das UFEs em que participam os termos. Nesse passo, definimos que os segmentos textuais extraídos deveriam contemplar as referências denotativas ao âmbito futebolístico, mas em relação metafórica com o domínio da política, para posterior análise dos eventuais processos de metaforização. A Figura 5 ilustra o recurso de ampliação dos contextos de ocorrência, na análise das linhas de concordância, para seleção das UFEs.

FIGURA 5 - Processo de identificação de UFEs em relação metafórica

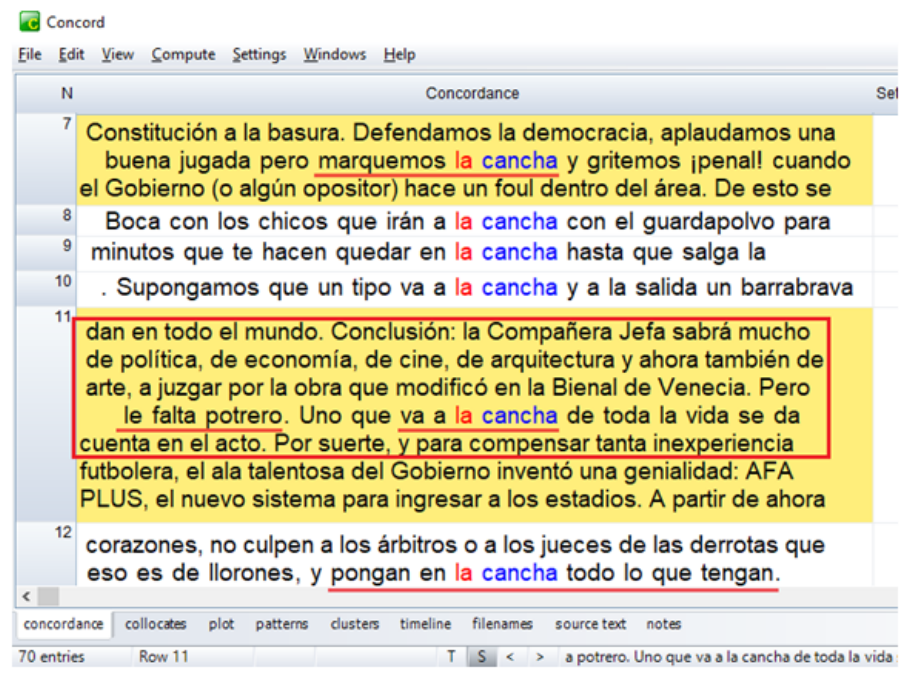

Fonte: WordSmith Tools (SCOTT, 2016)

Na figura anterior, é possível apreciar a relação entre política e futebol, nos fragmentos em destaque. Assim, nas linhas de concordância 7 e 11, apenas para ilustrar o procedimento de identificação das UFEs 
em relação metafórica, ${ }^{12}$ percebemos que o assunto é a democracia ou o governo e que há alusões diretas à prática do futebol, a saber: aplaudir una buena jugada, marcar la cancha, gritar penal, hacer un foul dentro del área, faltarle potrero, ir a la cancha, inexperiencia futbolera, ingresar a los estadios, poner todo en la cancha.

Os campos lexicais e consequentes campos semânticos de determinados vocábulos identificados no corpus, com pertinência ao domínio da prática do futebol e em relação metafórica com a política, estão resumidos, a seguir: Participantes (jogadores, posições no campo de jogo, técnicos, árbitros, dirigentes, torcida etc.); Locais para a prática do futebol (campo de jogo e suas partes específicas, de treino, estádios etc.); Jogadas (ataque, defesa, estratégias de jogo...); Partidas (amistosas, oficiais, duração, campeonatos, transmissão...); Partes do corpo humano (que intervêm no jogo, pê, cabeça, peito, mãos...); Materiais esportivos utilizados na prática de futebol (camisa, chuteira, caneleira...). Estes campos lexicais buscam agrupar, num primeiro nível, as ocorrências dos candidatos a termos extraídos. Por meio da análise das linhas de concordância que geramos a partir de cada termo, pudemos apreciar em contexto a abrangência semântica de cada ocorrência, conforme o reconhecimento das diferentes UFEs. O mesmo procedimento foi aplicado para a limpeza dos resultados, isto é, para exclusão tanto dos candidatos que não se confirmassem enquanto termos, como das ocorrências de UT que não correspondessem ao domínio do futebol, mas de outros esportes. Assim, como será observado na próxima seção, embora a UT cancha tenha reportado determinada frequência, nem todas foram correspondentes ao âmbito futebolístico.

Para o tratamento e sistematização dos dados em planilha Excel, incluímos um número para a entrada de cada item lexical candidato a termo, conforme ordem alfabética, a frequência de ocorrência no corpus, a frequência atestada enquanto UT, o quantitativo de tipos de UFEs identificadas para cada UT, a descrição das combinatórias léxicas e dos fraseologismos identificados e os contextos metafóricos de ocorrência.

A próxima seção apresenta as análises das UFEs formadas com as UTs cancha e canchereada, identificadas no corpus de estudo na realização de processos de metaforização.

\footnotetext{
${ }^{12}$ As análises dos fragmentos que compõem o recorte da pesquisa apresentado neste artigo serão desenvolvidas na próxima seção.
} 


\section{Análise}

Dos dados obtidos e classificados sob o campo semântico Locais para a prática do futebol, selecionamos cancha e um de seus derivados para esta análise. Pela análise das linhas de concordância, o item lexical cancha reportou 79 ocorrências no Corpus AleBores, das quais 70 foram corroboradas como UTs, no escopo de nossa pesquisa, pelo fato de fazerem referência específica ao futebol. As demais dizem respeito a campos de Tênis, Rugby, Polo ou Golfe, esportes também populares na Argentina.

CANCHA. $f$. Terreno utilizado para a prática de alguns esportes como o futebol. Por extensão, estádio. (f 70)

Pela análise das combinatórias léxicas com cancha, identificamos diversas UFEs com sentido metafórico, como entrar a la cancha, ir a la cancha, dejar / poner (todo) en la cancha, sacar a la cancha, sacar de la cancha, salir a la cancha, além de outras, em que os participantes envolvidos são personagens da política ou do governo, mas que serão objeto de estudo em outras publicações. Neste artigo, passamos a analisar as ocorrências identificadas com MARCAR como colocado de CANCHA. Observamos 6 ocorrências da colocação MARCAR + CANCHA, que representam 8,6\% da frequência da UT (70) no corpus. Não encontramos, em nenhum dos dicionários consultados, a combinatória léxica dicionarizada. Num primeiro momento, definiremos a colocação em sentido denotativo, no âmbito do futebol, para depois analisá-la à luz dos segmentos de ocorrência no corpus.

MARCAR(LE) LA CANCHA [uma pessoa a outra] / ESTAR LA CANCHA MARCADA. 1. Em campos com gramado natural, marcar com cal as linhas laterais, finais, do meio do campo, além das áreas (grande, pequena e semicírculo) dos gols, ângulos de escanteios e pontos para cobrança de pênalti em cada área e desde onde são iniciados os jogos, no meio do campo. 2. Definir uma estratégia de jogo e/ou um posicionamento de jogadores em campo, que dificultam as ações do adversário. (f 6) 
(01) No permita que ninguna Diana Conti le amargue la vida cuando sugiere que hay que tirar la Constitución a la basura. Defendamos la democracia, aplaudamos una buena jugada, pero marquemos la cancha y gritemos ipenal! cuando el Gobierno (o algún opositor) hace un foul dentro del área.

(02) La Compañera Jefa acaba de declarar "a este gobierno nadie le marca la cancha”. Lamento avisar que está equivocadísima.

(03) Todos le marcamos la cancha.

(04) Hasta mi hija de un año y medio, mi Minina!!!, en cuanto se despierta y antes de tomar su mema lo primero que hace es marcarle la cancha al gobierno.

(05) Porque ella, como todos nosotros, nació en suelo argentino, bajo la tutela de un librito que se llama Constitución Nacional donde está toda la cancha marcadita. Les guste o no les guste.

(06) En el momento más duro de su gobierno, después de aprobar a la fuerza el acuerdo con Irán, les salió una bolilla impensada: Francisco. Nadie se avivó que en la esquina de la Casa Rosada vivía un potencial Papa (de hecho, habia salido segundo en la votación anterior), y de un día para el otro apareció un argentino con mucho más poder que Ud. marcando la cancha y frenando por peso propio ciertos aires de descontrol.

A compreensão das UFEs, formadas a partir de marcar la cancha que identificamos no corpus, demandou um conhecimento prévio quanto ao sentido das marcações já existentes no campo de futebol e suas implicações. As marcas, feitas normalmente de cal, delimitam as linhas laterais e finais do campo de jogo. A linha central do meio de campo separa os setores de ataque e de defesa de cada um dos times. Dentre as demais marcações, essas já bastariam para entender que cada time tem, no jogo, diversas possibilidades de distribuir seus jogadores, tanto no ataque quanto na defesa, a partir de estratégias e esquemas ofensivos e defensivos. A UFE marcar(le) la cancha equivale a mostrar para o rival o modo como poderá ou não jogar, que não vai poder jogar da maneira que quiser, pois as marcações no campo estabelecem limites, assim como as estratégias de seu adversário. No fórum de discussão do dicionário WordReference, há uma consulta sobre o significado da frase. Entre as respostas, consta em inglês "Marcar la cancha means to put the limits to (a situation)". ${ }^{13}$

\footnotetext{
${ }^{13}$ Informação encontrada em: https://forum.wordreference.com/threads/est\%C3\%A1marcando-la-cancha.2324051/. Acesso em: 16 jun. 2020.
} 
Metaforicamente, transportado ao domínio alvo da política, esse fraseologismo futebolístico aponta para o estabelecimento de limites aos governantes, na época Cristina Kirchner. Assim, ao afirmar em (2) "a este gobierno nadie le marca la cancha", a presidente manifestava que ninguém iria definir limites a seu governo, que ninguém iria marcar para eles como deveriam ser as coisas. Como tópico da metáfora linguística temos "a este gobierno" e como veículo "nadie le marca la cancha". Com isso, inferimos que o governo é representado como um time de futebol pelo uso que a mandatária faz dessa colocação, e que escolhe o modo como quer jogar e não aceita que ninguém lhe imponha regras. Cancha, neste caso, é o terreno de ação governamental. Borensztein, colunista de Humor Político, reage a essa afirmação, destacando em (5) que todo aquele que habita sob solo argentino está regido pela Constituição Nacional, "donde está toda la cancha marcadita". Essa réplica dá a entender que a expressão destaca o modo como as coisas devem ser. Assim, as leis que estabelecem as normas de convivência no território argentino, definidas na Constituição (tópico), são um campo de futebol (veículo), com regras bem definidas que devem ser respeitadas.

Em outra referência à Constituição Nacional, o articulista aconselha o leitor a não se deixar amargurar a vida, quando uma exdeputada kirchnerista teria sugerido jogar no lixo a Constituição, e complementa em (1) dizendo "Defendamos la democracia, aplaudamos una buena jugada, pero marquemos la cancha y gritemos ipenal! cuando el Gobierno (o algún opositor) hace un foul dentro del área". Ou seja, gritar pênalti, se o governo ou a oposição, enquanto tópico, fizerem falta dentro da área, isto é, em caso de cometerem uma falta grave passível de punição, significa fazer valer as regras, isso é marcar la cancha, como veículo da metáfora linguística. Novamente, cometer uma infração no jogo acarreta uma punição; o uso de marcar la cancha corresponde a estabelecer limites com consequências previsíveis para quem infrinja as normas. Assim, o campo de ação do governo é um campo de futebol, una cancha, com regras marcadas.

No fragmento (6), a UFE no corpus está relacionada ao aparecimento da figura do Papa Francisco, que surgiu "marcando la cancha" e com muito mais poder do que a presidente Cristina Kirchner. O colunista destaca que, embora o governo não cogitasse essa possibilidade, teria que passar a lidar com um Papa argentino, que passaria a ter ingerência quanto ao respeito às regras do jogo, no alcance das ações do 
governo. Desse modo, podemos apreciar que o uso de marcar la cancha se aplica, por um lado, no sentido de quem não quer que ninguém marque limites a seu governo e, por outro lado, de que toda a sociedade, o Papa e a própria Constituição estabelecem marcas, definem limites, que precisam ser respeitados dentro do jogo.

Nas ocorrências (1) e (3), o articulista faz um apelo ao leitor, marcado pelo uso da primeira pessoa do plural no Imperativo afirmativo e no Presente do modo Indicativo: "aplaudamos una buena jugada pero marquemos la cancha y gritemos ipenal!" e em "Todos le marcamos la cancha". Esses usos podem ser entendidos como referência à torcida de um time imaginário, representando o povo argentino, que tanto alentaria as boas ações dos governantes quanto questionaria a falta de limites ou suas atitudes agressivas, violentes. Desse modo, o autor da coluna poderia ser compreendido como membro ou líder de uma torcida, da qual fazem parte o próprio colunista e os leitores. Palacios e Chacra (2014, p. 83) afirmam que "O torcedor argentino usa com frequência a primeira pessoa do plural para explicar como anda seu time: estamos indo bem ou hoje à tarde jogaremos contra $X$ '. Isto é, o torcedor se enxerga como parte integrante e ativa do time, não apenas como espectador.

No intuito de verificarmos a incidência de marcar la cancha fora de nosso Corpus AleBores, por meio da busca no Corpus del Español, nas versões Dialetal e NOW (DAVIES, 2016, 2018), utilizando cancha como base do fraseologismo e marcar como colocado, com a função de lematização ativada num horizonte de 4 palavras à esquerda e 4 à direita, obtivemos 283 resultados na versão dialetal desses corpora. Cabe destacar que esses corpora possuem uma extensão de 2 e 5,5 bilhões de palavras, respectivamente. Como corpus de consulta e ponto de contraste, entre esses e o Sketch Engine (KILGARRIFF, 2019), o Corpus del Español na versão dialetal (DAVIES, 2016) foi o que se mostrou mais pertinente dos três para esta pesquisa. $\mathrm{O}$ país que registrou maior frequência de ocorrência foi Argentina (122), seguido pelo Uruguai (48). Os demais resultados ficaram distribuídos entre os outros países hispano-falantes, com baixa frequência, como Espanha (5) e México (4), por exemplo. Pela frequência atestada, a análise dos resultados separados por países permitiu constatar que a UFE estudada corresponde a um uso próprio rio-platense. Analisando os resultados, de modo geral, a UFE ocorreu em frases que tratam sobre política e justiça, envolvendo membros de partidos políticos, governantes, juízes, ministros da Corte Suprema, legisladores, entre outros, como pode ser apreciado na próxima figura. 
FIGURA 6 - Busca por MARCAR + CANCHA

\begin{abstract}
de ex vicepresidente es que Sanz salió a marcar la cancha. En una extensa entrevista $\epsilon$ de votos en barrios con más delitos - salió a marcar cancha y a advertir que si no fuerá ! local dijo como para iniciar la conversación y marcar la cancha... Luego de esta aclara 'ASO en la mano, Cristina decidió marcar bien la cancha para todos aquellos que por a żrupo intentó durante estos dos últimos años marcar la cancha, utilizando periodistas que Cristina se haga referente pero en serio y marque la cancha persistentemente. Eso da con c :ultural, es auspicioso que gente como BS marque la cancha. Tus reflexiones sobre lo implicito 0 acionales importa más la política, el a mí no me marque la cancha, la politiquería de punteros, $q$ a Cristina pero muy diferente es que te marque la cancha las corporaciones. A lo ya conocido so $r$ varones que no están acostumbrados a que una mujer les marque la cancha y les diga sí o no.
\end{abstract}

Fonte: Corpus del Español (DAVIES, 2016)

Dentre os derivados de cancha identificados no corpus, extraímos diversos vocábulos, alguns dos quais se configuraram UTs, como canchero e cancherear, que denotam uma ostentação de determinada habilidade (tener cancha), confiança, no desempenho de uma atividade, por exemplo no controle da bola, no jogo do futebol. Além dessas, também registramos o substantivo canchereada, que passamos a definir e para o qual tampouco encontramos registro nos dicionários consultados.

CANCHEREADA. $\boldsymbol{f}$. Jogada feita com malandragem, com a esperteza de quem demonstra possuir habilidade, domínio, técnica ou experiência, para conseguir que uma manobra ilegal ou contra as regras (no jogo, um gol de mão, por exemplo) passe como totalmente válida. (f 4)

(7) Obviamente, Macri lo vetó. ¿Está loco? No, al igual que CFK en su momento, ahora es él quien no tiene la guita para financiar esta canchereada.

(8) Otro ejemplo, es el bono a 100 años, una canchereada del gobierno para decir "mirá que confianza que nos tienen".

(9) Con el dólar a 15, la canchereada de la arquitecta egipcia nos costó 60.000 millones de pesos más.

(10) El tipo le mandó a la diputada Cerruti un papelito de morondanga pidiéndole simpáticamente que no meta a sus hijas menores de edad en el tema de las famosas offshores. Una canchereada de pescador. O sea, sacó la caña y empezó suavecito con el lengue lengue. 
Nos quatro fragmentos anteriores, observa-se que se trata de manobras realizadas por governantes, jogadas políticas, levadas à prática com a habilidade e malandragem ou catimba de um jogador de futebol em campo, que utilizaria artimanhas para conseguir enganar o adversário, seja para fazer um gol, para fazer um drible ou tomar a bola, muitas das vezes de maneira desleal. Assim, em (7) observamos uma situação em que os ex-presidentes argentinos, CFK e Macri, por falta de capital (guita), precisaram recorrer a manobras que poderiam ser questionáveis, devido à ginga utilizada para esquivar um mau momento. Em (8) e (9), percebe-se que as malandragens são atribuídas ao governo diretamente ou por meio de um dos apelidos utilizados pelo colunista em referência a Cristina Kirchner, arquitecta egipcia. Em ambos os fragmentos há novamente uma relação com questões econômicas que, lançando mão de outras metáforas futebolísticas para explicá-las, tentam ser dribladas pelos governantes, por meio de jogadas que poderiam ser consideradas desleais. Também em (10), quando a referência à participação de familiares de políticos em empresas "offshores" é feita como "una canchereada de pescador", isto é, assim como uma história de pescador, em que também haveria uma jogada, por meio da qual se buscaria alcançar algum benefício por caminhos duvidosos. Nos quatro fragmentos em análise, os personagens do domínio político são o tópico da metáfora linguística, enquanto canchereada funciona como veículo, que transfere traços concretos do plano do futebol para o domínio mais abstrato da política.

Na versão dialetal do Corpus del Español (DAVIES, 2016), a busca lematizada de canchereada reportou 33 ocorrências do termo, sendo 20 no singular e 13 no plural, e 30 dessas ocorrências da Argentina, o que confirma tratar-se de um argentinismo. Num dos fragmentos encontrados nesse corpus, identificamos a explicação do que seria uma canchereada, dada por um jogador: "Bajarla [la pelota] con una mano se podía confundir con una canchereada también. Sí, se puede confundir, yo hacía cosas que parecían canchereadas pero eran recursos de una técnica futbolística que yo noté que ya la iba teniendo de chico". ${ }^{14}$ Desse modo, é possível ver que estratégias ou manobras políticas são jogadas de futebol, feitas também com malandragem, como verdadeiras canchereadas. A

\footnotetext{
${ }^{14}$ Disponível em: http://www.elgrafico.com.ar/2012/04/25/C-4186-amadeo-carrizo-aunno-concibo-a-river-en-la-b-llore-mucho-con-el-descenso.php. Acesso em: 17 mai. 2020.
} 
próxima figura ilustra um recorte dos resultados encontrados no Corpus del Español, na versão dialetal.

FIGURA 7 - Busca por CANCHEREADA

\begin{abstract}
a la Rosada se le ocurre una nueva canchereada? ¿ No se dan cuenta de que esto
n que tu opinión no puede escribir se sin una canchereada como la de catedrátric

un mal análisis. Coincido en que la canchereada de jugar con acrónimos y siglas

I también conseguía lo opuesto (no caer en la canchereada). Con sus defectos y pi

ste blog desde entonces, no hay ninguna canchereada al respecto. Lo que menos

re, con esa dispersión de boca llena y canchereada entre compañeros de elenco. I

No me ensucies más, menos desde la canchereada. Si querés volvemos a hacer dı
\end{abstract}

Fonte: Corpus del Español (DAVIES, 2016)

\title{
5 Considerações
}

Encerrando este trabalho, depois da fundamentação teórica, descrição metodológica e das análises feitas a partir de um recorte de nossa pesquisa, fundamentalmente a partir do termo cancha, enquanto local para a prática de futebol, podemos traçar algumas considerações.

A pertinência a esta pesquisa dos pressupostos teóricos sobre os quais discorremos, na abordagem da Terminologia, em especial das UFEs, da Teoria da Metáfora Conceptual e da LC, ficou demonstrada pelo estabelecimento de diversos pontos de convergência. A recorrência de termos do domínio fonte mais concreto do futebol, em referência ao domínio alvo mais abstrato da política, a presença de um núcleo enquanto UT nas UFEs, a formação das metáforas linguísticas com tópicos do âmbito político e veículos do meio do futebol, tudo mediado pela exploração empírica de um corpus com os recursos, ferramentas e princípios de pesquisa da $\mathrm{LC}$, dão conta desse ponto de confluência dessas diversas vertentes teóricas. Por outro lado, a presença da cultura do futebol na vida diária da sociedade, observada nos trabalhos brasileiros revistos assim como nesta pesquisa, provavelmente fazendo parte em alguma medida do vocabulário popular, acaba sendo invocada por meio de expressões típicas desse domínio, tanto pela imprensa quanto no meio político, com diversos propósitos, mas funcionando para metaforizar situações abstratas em diversos âmbitos. 
Após a compilação do Corpus AleBores, preparação, armazenamento e tratamento com as diferentes ferramentas do programa WST, por meio do levantamento dos dados, analisamos diferentes listas de palavras e de palavras-chave, tomando por base diferentes critérios e valores adotados, no intuito de fazer a extração terminológica do domínio do futebol. Para isso, foi necessário realizar diferentes testes com o corpus de estudo, em contraste com um corpus de referência. $\mathrm{O}$ procedimento que se mostrou mais eficaz, isto é, que reportou o maior número de candidatos a termo, foi o escrutínio cuidadoso da lista de palavras extraída pela WordList.

Como descrito nas seções anteriores, a partir dos candidatos a termo geramos as linhas de concordância e, pela análise das ocorrências em contexto, identificamos as formações fraseológicas com participação dos termos. Desse modo, foi possível extrair UFEs, os fragmentos de ocorrência e descrever a formação das diferentes combinatórias léxicas, assim como a relação estabelecida nos processos de metaforização identificados e analisados. Todos os procedimentos foram detalhados do modo pormenorizado, uma vez que a replicação metodológica é um fator presente e de relevância nas pesquisas que envolvem a LC e a Terminologia. Cabe também destacar que a LC viabilizou neste trabalho mais do que uma sequência de procedimentos metodológicos ou de um modo de olhar para os dados, uma vez que aliada ao auxílio na identificação dos fatos linguísticos, observados na estrutura aparente do corpus, nossa introspecção foi conduzida à percepção das ocorrências metafóricas. O mapeamento da subjacência das metáforas conceptuais, enquanto fenômeno cognitivo materializado em metáforas linguísticas, a partir da exploração e indagação de corpora, são indícios significativos sobre o poder de teorização da LC a respeito da linguagem. Desta maneira, os trabalhos empíricos da LC contribuem para o avanço das pesquisas em metáfora conceptual e, num plano mais amplo, na Linguística Cognitiva.

Tal como discutido na seção de Análise, identificamos relações metafóricas entre os domínios do futebol e da política, que corroboram nossa hipótese inicial: existem aspectos cognitivos, linguísticos e pragmáticos entrelaçados e englobados por uma dimensão cultural mais ampla, que perpassa os domínios do futebol e da política e que somente é acionada a partir de traços e vestígios identificados no processo de leitura do texto. $\mathrm{O}$ reconhecimento de determinadas marcas linguísticas 
nos textos, especificamente as UFEs que acionam nas lembranças do leitor o domínio do futebol, transferem características dessa área, que passam a ser assimiladas para a compreensão do outro domínio que é metaforizado, o campo da política. Nesse sentido, por meio destas análises, conseguimos identificar as seguintes metáforas conceptuais no corpus, que se mostraram abundantes e recorrentes: o terreno das ações políticas é um campo de futebol; marcar o campo de jogo é estabelecer limites no âmbito da política; política é futebol; políticos são jogadores; manobras ou estratégias políticas são jogadas de futebol, inclusive malandragens (canchereadas).

\section{Declaração de contribuição de cada autor}

Enquanto autores, declaramos que desenvolvemos todos os trabalhos pertinentes a este artigo conjuntamente, desde a concepção e recorte, a partir de uma pesquisa maior em desenvolvimento, passando por todas as etapas de redação da fundamentação teórica, descrição metodológica, análises do corpus, até as considerações e revisões que se fizeram necessárias. Para facilitar os trabalhos, os autores compartilhamos uma pasta no OneDrive, contendo o texto do artigo, parte da bibliografia utilizada e arquivos com resultados do WST.

\section{Referências}

ALVES, M. A representação do Brasil no ensino de espanhol: um estudo diacrônico baseado em corpus de textos acadêmicos. 2013. Relatório (Iniciação Científica) - Instituto de Letras e Linguística da Universidade Federal de Uberlândia, Uberlândia, 2013.

ANANÍA, P. Diccionario inmoral de los argentinos. Buenos Aires: Vergara, 2005.

BERBER SARDINHA, T. As metáforas do presidente Lula na perspectiva da Linguística de Corpus: $\mathrm{O}$ caso do Desenvolvimento. D.E.L.T.A., São Paulo, v. 26, n. 1, p. 163-190, 2010. DOI: https://doi.org/10.1590/S010244502010000100007

BERBER SARDINHA, T. Pesquisa em Lingüistica de Corpus com WordSmith Tools. Campinas: Mercado das Letras, 2009. 
BERBER SARDINHA, T. Lula e a metáfora da conquista. Linguagem em (dis)curso, Tubarão, n. 8, v. 1, p. 93-120, 2008. DOI: https://doi. org/10.1590/S1518-76322008000100005

BERBER SARDINHA, T. Metáfora. São Paulo: Parábola Editorial, 2007a.

BERBER SARDINHA, T. Análise de metáfora em corpora. Ilha do Desterro, Florianópolis, n. 52, p. 167-199, 2007 b.

BERBER SARDINHA, T. Lingüistica de corpus. Barueri: Manole, 2004.

BEVILACQUA, C. R. Unidades Fraseológicas Especializadas Eventivas: descripción y reglas de formación en el ámbito de la energía solar. 2004. 243f. Tese (Doctorado en Lingüística Aplicada) - Institut Universitari de Lingüística Aplicada, Universidad Pompeu Fabra, 2004.

BEVILACQUA, C. R. Unidades Fraseológicas Especializadas: estado de la cuestión. Trabajo de investigación. Barcelona: Institut Universitari de Lingüística Aplicada, 1999.

BEVILACQUA, C. R. Unidades Fraseológicas Especializadas: novas perspectivas para sua identificação e tratamento. Organon, Porto Alegre, n. 26, p. 1-8, 1998. DOI: https://doi.org/10.22456/2238-8915.29562

BORBA, F. S. Dicionário de usos do português do Brasil. São Paulo: Ed. Ática, 2002.

BORENSZTEIN, A. Barcarce, We Have a Problem. Clarín, Buenos Aires, 22 abr. 2018.

BOSQUE, I.; DEMONTE, V. Gramática Descriptiva de la Lengua Española. 2. ed. Madrid: Espasa Calpe, 1999. Tomos 1, 2 e 3.

CABRÉ, M. T. La Terminología: Representación y Comunicación. Barcelona: IULA / Universitat Pompeu Fabra, 2005.

CABRÉ, M. T. Terminología y Lingüística: la teoría de las puertas abiertas. Estudios de Lingüística del Español (ELiEs), Barcelona, v. 16, [s.p.], 2002.

CABRÉ, M. T. La terminología: teoría, metodología, aplicaciones. Traducción castellana: Carles Tebé. Barcelona: Editorial Empúries, 1993. 
CABRÉ, M. T.; ESTOPÀ, R.; LORENTE, M. Terminología y Fraseología. In: SIMPOSIO DE TERMINOLOGÍA IBEROAMERICANA, V., 1996, Ciudad de México. Anais [...]. Ciudad de México: Red Iberoamericana de Terminología, 1996. p. 1-23.

CORPAS PASTOR, G. Diez años de investigación en fraseología: análisis sintáctico-semánticos, contrastivos y traductológicos. Madrid: Iberoamericana, 2010.

DAVIES, M. Corpus del Español: Web/Dialectos, 2016. Disponível em: https://www.corpusdelespanol.org/web-dial/. Acesso em: 25 set. 2019.

DAVIES, M. Corpus del Español: NOW, 2018. Disponível em: https:// www.corpusdelespanol.org/now/. Acesso em: 15 ago. 2019.

DEIGNAN, A. A gramática das metáforas linguísticas. In: SHEPHERD, T. M. G.; BERBER SARDINHA, T; VEIRANO PINTO, M. (org.). Caminhos da Linguística de Corpus. Campinas: Mercado de Letras, 2012. p. 65-86.

DEIGNAN, A. Metaphor and Corpus Linguistics. Amsterdam-/ Philadelphia: John Benjamins Publishing, 2005. DOI: https://doi. org/10.1075/celcr.6

FONTANARROSA, R; SANZ, T. El fútbol argentino: pequeño diccionario ilustrado. Buenos Aires: Clarín/Aguilar, 1994.

GOVERNATORI, G.; LAROCCA, R. ¡Qué lo parió, che!: Diccionario coloquial de los argentinos. Buenos Aires: Continente, 2014.

HOUAISS, A. Dicionário eletrônico Houaiss da língua portuguesa. Versão 3.0, 2009.

KILGARRIFF, A. Sketch Engine. Disponível em: http://sketchengine. co.uk/. Acesso em: 3 nov. 2019.

KRIEGER, M. G.; SANTIAGO, M. S.; CABRÉ, M. T. Terminologia em foco: uma entrevista comentada com Maria Teresa Cabré. Calidoscópio, São Leopoldo, RS, v. 11, n. 3, p. 328-332, 2013. DOI: https://doi. org/10.4013/cld.2013.113.11

LAKOFF, G; JOHNSON, M. Metaphors we live by. Chicago: The University of Chicago Press, 1980. 
MOLINER, M. Diccionario de uso del español. Edición electrónica, versión, 3.0. Madrid: Editorial Gredos, S.A.U., 2008.

ORENHA, A. Unidades Fraseológicas Especializadas: colocações e colocações estendidas em contratos sociais e estatutos sociais traduzidos no modo juramentado e não juramentado. 2009. 290f. Tese (Doutorado em Linguística Aplicada) - Instituto de Biociências, Letras e Ciências Exatas, Universidade Estadual Paulista, 2009.

ORENHA, A.; CAMARGO, D. C. de. A extração de Unidades Fraseológicas Especializadas a partir de corpora paralelos e comparáveis. The ESPecialist, São Paulo, v. 30, n. 1, p. 57-81, 2009.

PALACIOS, A. Os argentinos. São Paulo: Contexto, 2015.

PALACIOS, A.; CHACRA, G. Os hermanos e nós. São Paulo: Contexto, 2014.

PARODI, G. (org.). Géneros académicos y géneros profesionales: accesos discursivos para saber y hacer. Valparaíso: Ediciones universitarias de Valparaíso, 2008.

PARODI, G. Lingüistica de Corpus: de la teoría a la empiria. Madrid / Frankfurt: Iberoamericana / Vervuert, 2010. DOI: https://doi. org/10.31819/9783865278715

SCOTT, M. WordSmith Tools (7.0) [Programa computacional]. Liverpool: Lexical Analysis Software, 2016.

SPERANDIO, N. E. As metáforas de Lula: uma forma de legitimação. In: SIMPÓSIO INTERNACIONAL DE LETRAS E LINGUÍSTICA, 2009, Uberlândia. Anais [...]. Uberlândia: EDUFU, 2009. p. 1-11.

SPERANDIO, N. O Modelo Cognitivo Idealizado no processamento metafórico. 2010. 99f. Dissertação (Mestrado em Letras) - Universidade Federal de São João del Rei, São João del Rei, 2010. 